\title{
STUDI LITERATUR: PENGARUH ASUPAN ENERGI PROTEIN DAN RIWAYAT ASI EKSKLUSIF TERHADAP STUNTING
}

\author{
I Made Sudarta ${ }^{\bowtie}$, Syafruddin Ali Salaka \\ Jurusan Keperawatan Poltekkes Kemenkes Mamuju
}

\section{ARTICLE INFO \\ Article history \\ Submitted : 2021-10-15 \\ Revised : 2021-10-22 \\ Accepted : 2021-11-22 \\ Keywords: \\ Protein \\ Energy intake \\ Exclusive breastfeeding \\ Stunting}

\section{Kata Kunci: \\ Asupan Energi \\ Protein \\ ASI eksklusif \\ Stunting}

\begin{abstract}
The incidence of short toddlers commonly referred to as stunting is one of the nutritional problems worldwide. In $201722.2 \%$ or about 150.8 million toddlers in the world experienced stunting. The Integrated Toddler Nutrition Status Survey (SSGBI) by Balitbangkes Kemenkes Republik Indonesia in 2019 shows that the highest proportion of stunting is found in East Nusa Tenggara, West Sulawesi, and West Nusa Tenggara. The districts in West Sulawesi with the highest percentage of very short and short toddlers at the age of $0-59$ months in 2018 were Mamuju Regency which is $20.08 \%$ and $26.38 \%$. This study aims to determine the influence of protein and energy intake and exclusive breastfeeding history of breastfeeding on stunting events. This research is a literature review that summarizes some relevant literature. Articles searched using google scholar database. After the screening, 21 articles were eligible and met the criteria. There is an influence of protein and energy intake and exclusive breastfeeding on stunting. It is expected that the results of this study will become one of the educational materials and nursing interventions that can be applied in the health service in preventing stunting.

Kejadian balita pendek, yang biasa disebut sebagai stunting, adalah salah satu masalah gizi di seluruh dunia. Pada 2017 22,2\% atau sekitar 150,8 juta balita di dunia mengalami stunting. Survei Status Gizi Balita Terintegrasi (SSGBI) yang dilakukan oleh Balitbangkes Kemenkes Republik Indonesia pada tahun 2019 menunjukkan bahwa proporsi tertinggi stunting terdapat di Nusa Tenggara Timur, Sulawesi Barat, dan Nusa Tenggara Barat. Kabupaten di Sulawesi Barat dengan persentase balita usia $0-59$ bulan sangat pendek dan pendek tertinggi pada 2018 yaitu Kabupaten Mamuju sebesar $20,08 \%$ dan $26,38 \%$. Penelitian ini bertujuan untuk mengetahui pengaruh asupan energi dan protein serta riwayat ASI eksklusif terhadap kejadian stunting. Penelitian ini merupakan studi literatur yang merangkum beberapa literatur yang relevan. Artikel dicari dengan menggunakan database Google Scholar. Setelah dilakukan screening, 21 artikel memenuhi syarat dan memenuhi kriteria. Ada pengaruh asupan energi dan protein serta ASI eksklusif terhadap stunting. Diharapkan hasil penelitian ini akan menjadi salah satu bahan pendidikan dan intervensi keperawatan yang dapat diterapkan di pelayanan kesehatan dalam mencegah stunting.
\end{abstract}

Corresponding Author:

I Made Sudarta

Jurusan Keperawatan Poltekkes Kemenkes Mamuju

Telp. 085394003997

Email: sudharta.made@ gmail.com

\section{PENDAHULUAN}

Balita pendek atau yang biasa disebut dengan stunting merupakan salah satu masalah gizi yang dialami oleh balita di dunia saat ini. Pada tahun 2017 sekitar 22,2\% atau 150,8 juta balita di dunia mengalami stunting. Namun sudah mengalami penurunan jika dibandingkan dengan angka kejadian stunting pada tahun 2000 yaitu sebesar 32,6\% (Kemenkes RI, 2018).

Pada tahun 2017 diperkirakan lebih dari setengah balita stunting di dunia berasal dari
Asia (55\%) sedangkan lebih dari sepertiganya (39\%) tinggal di Afrika. Dari 83,6 juta balita stunting di Asia, proporsi terbanyak berasal dari Asia Selatan $(58,7 \%)$ dan proporsi paling sedikit di Asia Tengah $(0,9 \%)$ (Kemenkes RI, 2018).

Di Indonesia pada tahun 2018, angka kejadian balita sangat pendek dan pendek usia $0-59$ bulan sebanyak $11,5 \%$ dan $19,3 \%$. Kondisi ini meningkat dari tahun sebelumnya yaitu sebesar 9,8\% dan balita pendek sebesar 19,8\%. Provinsi dengan persentase tertinggi balita 
adalah Nusa Tenggara Timur, sedangkan terendah adalah DKI Jakarta (Kemenkes RI, 2020).

Hasil Survei Status Gizi Balita Terintegrasi (SSGBI) oleh Balitbangkes Kemenkes Republik Indonesia tahun 2019, diketahui bahwa proporsi stunting tertinggi terdapat di Nusa Tenggara Timur, Sulawesi Barat, dan Nusa Tenggara Barat. Hasil ini hampir sama dengan Riskesdas tahun 2018, dimana proporsi stunting tertinggi ada di Nusa Tenggara Timur, Sulawesi Barat, dan Aceh. Sedangkan untuk proporsi stunting terendah menurut SSGBI 2019 ada di Kepulauan Bangka Belitung, Kepulauan Riau dan Bali, menurut Riskesdas 2018 terdapat di Bali, DKI Jakarta, dan DI Yogyakarta (Kemenkes RI, 2020).

Berdasarkan hasil RISKESDAS Tahun 2018. Prevalensi balita sangat pendek dan pendek usia 0 - 59 bulan di Sulawesi Barat adalah $16,2 \%$ dan $25,4 \%$. Kabupaten dengan persentase tertinggi adalah Kabupaten Mamuju yaitu sebesar $20,08 \%$ dan $26,38 \%$, sedangkan kabupaten dengan persentase terendah adalah Kabupaten Mamuju Utara yaitu sebesar 11,29\% dan 23,51\% (Badan Penelitian dan Pengembangan Kesehatan, 2018).

Stunting pada anak berdampak pada penurunan sistem imunitas tubuh dan meningkatkan risiko terkena penyakit infeksi, kecenderungan menderita penyakit tekanan darah tinggi, diabetes, jantung dan obesitas akan lebih tinggi ketika anak stunting menjadi dewasa. Selain itu anak dengan stunting mempunyai rata-rata IQ 11 poin lebih rendah dibandingkan dengan anak yang tidak stunting (Lestari, W., Margawati, A., \& Rahfiludin, Z, 2014).

Rendahnya pemberian ASI eksklusif menjadi salah satu pemicu terjadinya stunting pada anak balita, sebaliknya pemberian ASI yang baik akan membantu menjaga keseimbangan gizi anak sehingga tercapai pertumbuhan anak yang normal dan optimal (Alrahmad, A. H., Miko, A., \& Hadi, A. 2010). Asupan nutrisi yang tidak seimbang berpengaruh terhadap pemenuhan zat gizi. Walaupun banyak faktor yang mempengaruhi, asupan gizi merupakan faktor langsung penyebab terjadinya stunting pada balita (Fitri, L., Ritawani, E., \& Mentiana, Y. 2020).

Berdasarkan latar belakang di atas maka rumusan masalah dalam penelitian ini adalah "apakah asupan energi dan protein serta riwayat ASI eksklusif berhubungan dengan stunting?. Adapun tujuan dari penelitian ini adalah untuk menganalisis pengaruh asupan energi protein dan riwayat ASI eksklusif terhadap kejadian stunting. Diharapkan penelitian ini dapat memberikan informasi bagi peneliti untuk pengembangan ilmu keperawatan khususnya tentang faktor risiko stunting.

\section{METODE PENELITIAN Jenis Penelitian}

Penelitian ini merupakan studi literatur (literature review) yang merangkum beberapa literatur relevan. Study literatur atau studi pustaka adalah teknik dalam melaksanakan penelitian dengan mengkaji atau meninjau secara langsung pengetahuan, gagasan, atau temuan yang terdapat dalam literatur dengan merumuskan kontribusi teoretis dan metodologis berdasarkan topik.

\section{Waktu Penelitian}

Pencarian artikel dimulai pada tanggal 17 Juni 06 Agustus 2021

\section{Pengumpulan Data}

Artikel dicari dengan menggunakan database google scholar dengan kata kunci faktor-faktor yang berhubungan dengan stunting, pengaruh asupan energi protein terhadap stunting dan pengaruh riwayat ASI eksklusif terhadap stunting. Setelah dilakukan screening, eligbility dan include maka diperoleh 21 artikel yang memenuhi kriteria.

\section{Kriteria inklusi}

a. Artikel dengan full text

b. Artikel yang terpublikasi secara nasional, Google Scholar

c. Artikel yang sesuai dengan kata kunci.

d. Artikel diatas tahun 2011

\section{Kriteria eksklusi}

a. Artikel hanya abstrak saja

b. Artikel di bawah tahun 2011

c. Artikel tidak sesuai dengan kata kunci

Penelitian ini mencari daftar referensi dari penelitian sebelumnya, diperoleh sebanyak 86 studi yang diambil melalui pencarian. Sebanyak 40 artikel dalam pembersihan, dan ada 21 artikel yang termasuk dalam kriteria. Setelah itu dilakukan tinjauan sistematis terhadap pertanyaan yang dirumuskan secara jelas yang menggunakan sistematik dan eksplisit metode untuk mengidentifikasi, memilih, dan menilai secara kritis penelitian 
yang relevan, dan untuk mengumpulkan dan menganalisis data dari studi yang termasuk dalam review.

\section{HASIL PENELITIAN}

Pada penelitian ini menggunakan 21 (dua puluh satu) artikel penelitian yang dipilih sesuai dengan topik. Tiga literatur membahas tentang pengaruh asupan energi protein terhadap stunting, 14 (empat belas) literatur membahas tentang pengaruh riwayat ASI eksklusif terhadap stunting dan tiga literatur membahas pengaruh keduanya yaitu pengaruh asupan energi protein dan pengaruh riwayat ASI eksklusif terhadap stunting.

Analisis sintesis grid pencarian literatur dijelaskan pada tabel berikut ini:

Tabel 1. Analisis Sintesis Grid Pencarian Literature

\begin{tabular}{|c|c|c|c|c|c|}
\hline No & Penulis & Judul Penelitian & $\begin{array}{c}\text { Metode } \\
\text { Penelitian }\end{array}$ & Instrumen & Hasil \\
\hline 1 & $\begin{array}{l}\text { Agustina } \\
\text { Dwi Utami, } \\
\text { Dono } \\
\text { Indarto, } \\
\text { Yulia Lanti } \\
\text { Retno Dewi }\end{array}$ & $\begin{array}{l}\text { Pengaruh Asupan } \\
\text { Nutrisi dan Faktor } \\
\text { Sosial Ekonomi } \\
\text { terhadap kejadian } \\
\text { Stunting pada Siswa } \\
\text { SD di Surakarta }\end{array}$ & $\begin{array}{c}\text { Studi } \\
\text { observasional } \\
\text { analitik, } \\
\text { menggunakan } \\
\text { desain cross } \\
\text { sectional }\end{array}$ & $\begin{array}{c}\text { Penelitian ini } \\
\text { menggunakan } \\
\text { kuesioner dan } \\
\text { pengukuran tinggi } \\
\text { badan untuk } \\
\text { pengumpulan data. }\end{array}$ & $\begin{array}{l}\text { Hasil statistik } \\
\text { menunjukkan bahwa } \\
\text { Kejadian Stunting } \\
\text { dipengaruhi oleh } \\
\text { asupan energi, asupan } \\
\text { protein, pendidikan } \\
\text { ibu, pendapatan } \\
\text { keluarga. }\end{array}$ \\
\hline 2 & $\begin{array}{l}\text { Sugiyanto, } \\
\text { Sumarlan }\end{array}$ & $\begin{array}{c}\text { Analisis faktor yang } \\
\text { berhubungan dengan } \\
\text { stunting pada balita } \\
\text { usia } 25-60 \text { bulan di } \\
\text { wilayah kerja } \\
\text { puskesmas Limbong } \\
\text { Kabupaten Luwu } \\
\text { Utara }\end{array}$ & $\begin{array}{c}\text { Rancangan } \\
\text { penelitian } \\
\text { menggunakan } \\
\text { desain Cross } \\
\text { Sectional }\end{array}$ & Kuesioner & $\begin{array}{l}\text { Asupan energi, asupan } \\
\text { protein, pemberian ASI } \\
\text { Eksklusif berhubungan } \\
\text { dengan kejadian } \\
\text { stunting pada balita } \\
\text { usia } 25 \text { - } 60 \text { bulan di } \\
\text { wilayah kerja } \\
\text { Puskesmas Limbong } \\
\text { Kabupaten Luwu Utara }\end{array}$ \\
\hline 3 & $\begin{array}{l}\text { Nilatul Izah, } \\
\text { Evi Zulfiana, } \\
\text { Nora } \\
\text { Rahmanindar }\end{array}$ & $\begin{array}{c}\text { Analisis Sebaran } \\
\text { Dan Determinan } \\
\text { Stunting Pada Balita } \\
\text { Berdasarkan Pola } \\
\text { Asuh (Status } \\
\text { Imunisasi dan } \\
\text { Pemberian ASI } \\
\text { Eksklusif) }\end{array}$ & $\begin{array}{c}\text { Kuantitatif } \\
\text { dengan } \\
\text { desain } \\
\text { casecontrol }\end{array}$ & Kuesioner & $\begin{array}{l}\text { Pola asuh pemberian } \\
\text { ASI eksklusif } \\
\text { berpengaruh terhadap } \\
\text { kejadian stunting pada } \\
\text { balita dimana didapat } \\
\text { nilai } p=0,002(<0,05) .\end{array}$ \\
\hline 4 & $\begin{array}{l}\text { Welmince } \\
\text { Ina Lobo, } \\
\text { Anna Henny } \\
\text { Talahatu, } \\
\text { Rut Rosina } \\
\text { Riwu }\end{array}$ & $\begin{array}{c}\text { Faktor penentu } \\
\text { kejadian stunting } \\
\text { pada anak balita di } \\
\text { Wilayah Kerja } \\
\text { Puskesmas Alak } \\
\text { Kota Kupang }\end{array}$ & $\begin{array}{c}\text { Jenis } \\
\text { penelitian } \\
\text { survei } \\
\text { analitik } \\
\text { dengan } \\
\text { rancangan } \\
\text { cross } \\
\text { sectional. }\end{array}$ & Kuesioner & $\begin{array}{l}\text { Hasil penelitian } \\
\text { menunjukkan tingkat } \\
\text { kecukupan energi dan } \\
\text { tingkat kecukupan } \\
\text { protein berhubungan } \\
\text { dengan stunting. }\end{array}$ \\
\hline 5 & $\begin{array}{l}\text { Farah Okky } \\
\text { Aridiyah, } \\
\text { Ninna } \\
\text { Rohmawati, } \\
\text { Mury } \\
\text { Ririanty }\end{array}$ & $\begin{array}{l}\text { Faktor-faktor yang } \\
\text { Mempengaruhi } \\
\text { Kejadian Stunting } \\
\text { pada Anak Balita di } \\
\text { Wilayah Pedesaan } \\
\text { dan Perkotaan }\end{array}$ & $\begin{array}{c}\text { Jenis } \\
\text { penelitian ini } \\
\text { adalah } \\
\text { analitik } \\
\text { observasional } \\
\text { dengan } \\
\text { desain cross- } \\
\text { sectional }\end{array}$ & Kuesioner & $\begin{array}{l}\text { Hasil analisis } \\
\text { menunjukkan bahwa } \\
\text { faktor yang } \\
\text { mempengaruhi } \\
\text { terjadinya stunting } \\
\text { pada anak balita yang } \\
\text { berada di wilayah } \\
\text { pedesaan dan } \\
\text { perkotaan adalah } \\
\text { pendidikan ibu, }\end{array}$ \\
\hline
\end{tabular}




\begin{tabular}{|c|c|c|c|c|c|}
\hline No & Penulis & Judul Penelitian & $\begin{array}{c}\text { Metode } \\
\text { Penelitian }\end{array}$ & Instrumen & Hasil \\
\hline & & & & & $\begin{array}{l}\text { pengetahuan ibu } \\
\text { mengenai gizi, } \\
\text { pemberian ASI } \\
\text { eksklusif, umur } \\
\text { pemberian MP-ASI, } \\
\text { tingkat kecukupan zink } \\
\text { dan zat besi, riwayat } \\
\text { penyakit infeksi serta } \\
\text { faktor genetik. }\end{array}$ \\
\hline 6 & $\begin{array}{l}\text { Khoirun } \\
\text { Ni'mah, Siti } \\
\text { Rahayu } \\
\text { Nadhiroh }\end{array}$ & $\begin{array}{c}\text { Faktor Yang } \\
\text { Berhubungan } \\
\text { Dengan Kejadian } \\
\text { Stunting Pada Balita }\end{array}$ & $\begin{array}{l}\text { Penelitian ini } \\
\text { merupakan } \\
\text { penelitian } \\
\text { observasional } \\
\text { analitik } \\
\text { dengan } \\
\text { desain studi } \\
\text { kasus } \\
\text { kontrol. }\end{array}$ & $\begin{array}{c}\text { Data primer } \\
\text { diperoleh melalui } \\
\text { wawancara } \\
\text { menggunakan } \\
\text { kuesioner kepada } \\
\text { ibu } \\
\text { balita. Status gizi } \\
\text { stunting diperoleh } \\
\text { melalui } \\
\text { pengukuran tinggi } \\
\text { badan balita } \\
\text { menggunakan } \\
\text { microtoise dengan } \\
\text { tingkat ketelitian } \\
0,1 \mathrm{~cm} \text {. }\end{array}$ & $\begin{array}{l}\text { Terdapat hubungan } \\
\text { antara panjang badan } \\
\text { lahir balita, riwayat } \\
\text { ASI eksklusif, } \\
\text { pendapatan keluarga, } \\
\text { pendidikan ibu dan } \\
\text { pengetahuan gizi ibu } \\
\text { terhadap kejadian } \\
\text { stunting pada balita. }\end{array}$ \\
\hline 7 & $\begin{array}{l}\text { Intje Picauly } \\
\text { dan Sarci } \\
\text { Magdalena } \\
\text { Toy }\end{array}$ & $\begin{array}{c}\text { Analisis Determinan } \\
\text { dan Pengaruh } \\
\text { Stunting Terhadap } \\
\text { Prestasi Belajar } \\
\text { Anak Sekolah di } \\
\text { Kupang dan Sumba } \\
\text { Timur, NTT }\end{array}$ & $\begin{array}{c}\text { Jenis } \\
\text { penelitian ini } \\
\text { adalah survei } \\
\text { analitik } \\
\text { dengan } \\
\text { menggunakan } \\
\text { desain cross } \\
\text { sectional. }\end{array}$ & $\begin{array}{l}\text { Microtoise, Food } \\
\text { Frequency } \\
\text { Questionnaires } \\
\text { (FFQ); kuesioner. } \\
\text { Nilai rata-rata } \\
\text { ulangan harian. }\end{array}$ & $\begin{array}{l}\text { Asupan protein, } \\
\text { Pendapatan keluarga, } \\
\text { pengetahuan gizi ibu, } \\
\text { pola asuh ibu, riwayat } \\
\text { penyakit infeksi, } \\
\text { riwayat imunisasi dan } \\
\text { pendidikan ibu } \\
\text { merupakan faktor } \\
\text { penyebab terjadinya } \\
\text { stunting. }\end{array}$ \\
\hline 8 & $\begin{array}{l}\text { Sri } \\
\text { Handayani, } \\
\text { Wiwin } \\
\text { Noviana } \\
\text { Kapota, Eka } \\
\text { Oktavianto }\end{array}$ & $\begin{array}{c}\text { Hubungan Status } \\
\text { ASI Eksklusif } \\
\text { dengan Kejadian } \\
\text { Stunting pada Batita } \\
\text { Usia } 24 \text { - 36 Bulan } \\
\text { di Desa Watugajah } \\
\text { Kabupaten } \\
\text { Gunungkidul }\end{array}$ & $\begin{array}{c}\text { Jenis } \\
\text { penelitian ini } \\
\text { adalah } \\
\text { penelitian } \\
\text { deskriptif } \\
\text { korelasional } \\
\text { menggunakan } \\
\text { pendekatan } \\
\text { cross } \\
\text { sectional }\end{array}$ & $\begin{array}{c}\text { Pemberian ASI } \\
\text { eksklusif diukur } \\
\text { menggunakan } \\
\text { kuesioner } \\
\text { pemberian ASI } \\
\text { eksklusif dan } \\
\text { stunting diukur } \\
\text { menggunakan } \\
\text { lembar observasi } \\
\text { antropometri dan } \\
\text { mikrotoise. }\end{array}$ & $\begin{array}{l}\text { Ada hubungan } \\
\text { pemberian ASI } \\
\text { eksklusif dengan } \\
\text { kejadian stunting pada } \\
\text { batita usia } 24-36 \\
\text { bulan di Desa } \\
\text { Watugajah, Kabupaten } \\
\text { Gunung kidul. }\end{array}$ \\
\hline 9 & $\begin{array}{l}\text { Cynthia, I } \\
\text { Wayan Bikin } \\
\text { Suryawan, } \\
\text { A.A Made } \\
\text { Widiasa }\end{array}$ & $\begin{array}{c}\text { Hubungan Riwayat } \\
\text { ASI Eksklusif } \\
\text { dengan Kejadian } \\
\text { Stunting pada Anak } \\
\text { Usia } 12-59 \text { Bulan } \\
\text { di RSUD Wangaya } \\
\text { Kota Denpasar }\end{array}$ & $\begin{array}{c}\text { Metode } \\
\text { potong } \\
\text { lintang } \\
\text { dengan } \\
\text { menggunakan } \\
\text { data sekunder } \\
\text { dari rekam } \\
\text { medis } \\
\end{array}$ & $\begin{array}{l}\text { Infantometer dan } \\
\text { timbangan bayi, } \\
\text { microtoise dan } \\
\text { timbangan berdiri. }\end{array}$ & $\begin{array}{l}\text { Tidak terdapat } \\
\text { hubungan yang } \\
\text { signifikan antara ASI } \\
\text { eksklusif dengan } \\
\text { stunting. }\end{array}$ \\
\hline 10 & $\begin{array}{l}\text { Dewi } \\
\text { Pusparani } \\
\text { Sinambela1, }\end{array}$ & $\begin{array}{c}\text { Pengaruh Riwayat } \\
\text { Pemberian ASI } \\
\text { Eksklusif dengan }\end{array}$ & $\begin{array}{c}\text { survei } \\
\text { analitik }\end{array}$ & $\begin{array}{c}\text { wawancara } \\
\text { langsung dengan } \\
\text { orang tua balita }\end{array}$ & $\begin{array}{l}\text { Terdapat pengaruh } \\
\text { yang signifikan antara } \\
\text { pemberian ASI }\end{array}$ \\
\hline
\end{tabular}




\begin{tabular}{|c|c|c|c|c|c|}
\hline No & Penulis & Judul Penelitian & $\begin{array}{c}\text { Metode } \\
\text { Penelitian }\end{array}$ & Instrumen & Hasil \\
\hline & $\begin{array}{l}\text { Putri } \\
\text { Vidiasari D } \\
\text { Nurul } \\
\text { Hidayah }\end{array}$ & $\begin{array}{c}\text { Kejadian Stunting } \\
\text { Pada Balita di } \\
\text { Wilayah Kerja } \\
\text { Puskesmas Teluk } \\
\text { Tiram Banjarmasin }\end{array}$ & & $\begin{array}{c}\text { menggunakan } \\
\text { checklist }\end{array}$ & $\begin{array}{l}\text { eksklusif dengan } \\
\text { kejadian stunting pada } \\
\text { balita. }\end{array}$ \\
\hline 11 & $\begin{array}{l}\text { Erika Fitria } \\
\text { Lestari, } \\
\text { Luluk } \\
\text { Khusnul } \\
\text { Dwihestie. }\end{array}$ & $\begin{array}{c}\text { ASI Eksklusif } \\
\text { Berhubungan } \\
\text { dengan Kejadian } \\
\text { Stunting Pada Balita }\end{array}$ & $\begin{array}{l}\text { Penelitian ini } \\
\text { merupakan } \\
\text { penelitian } \\
\text { kuantitatif } \\
\text { korelasi } \\
\text { dengan } \\
\text { metode case- } \\
\text { control }\end{array}$ & $\begin{array}{l}\text { Pengumpulan data } \\
\text { kejadian stunting } \\
\text { didapatkan dari } \\
\text { hasil rekapan } \\
\text { Puskesmas } \\
\text { Moyudan } \\
\text { sedangkan data } \\
\text { pemberian ASI } \\
\text { Eksklusif } \\
\text { menggunakan } \\
\text { kuesioner }\end{array}$ & $\begin{array}{l}\text { Berdasarkan hasil } \\
\text { penelitian } \\
\text { menunjukkan bahwa } \\
\text { adanya hubungan } \\
\text { pemberian ASI } \\
\text { eksklusif dengan } \\
\text { kejadian stunting } \\
\text { dibuktikan dengan } \\
\text { hasil uji chi Square, } \\
\text { dengan p-value }<\alpha \text { yaitu } \\
0,000 \text { dan nilai } \\
\text { koefisien korelasi } \\
\text { sebesar } 0,429 .\end{array}$ \\
\hline 12 & $\begin{array}{l}\text { Devillya } \\
\text { Puspita Dewi }\end{array}$ & $\begin{array}{c}\text { Status Stunting } \\
\text { Kaitannya dengan } \\
\text { Pemberian ASI } \\
\text { Eksklusif pada } \\
\text { Balita di Kabupaten } \\
\text { Gunung Kidul }\end{array}$ & $\begin{array}{l}\text { Penelitian ini } \\
\text { adalah } \\
\text { penelitian } \\
\text { kuantitatif } \\
\text { dengan } \\
\text { rancangan } \\
\text { case control } \\
\text { study }\end{array}$ & Kuesioner & $\begin{array}{l}\text { Kesimpulan } \\
\text { menunjukkan bahwa } \\
\text { status stunting } \\
\text { mempunyai kaitan } \\
\text { dengan pemberian ASI } \\
\text { Eksklusif pada balita di } \\
\text { Kabupaten Gunung } \\
\text { Kidul. }\end{array}$ \\
\hline 13 & $\begin{array}{l}\text { Sr. Anita } \\
\text { Sampe, } \\
\text { Rindani } \\
\text { Claurita } \\
\text { Toban, } \\
\text { Monica } \\
\text { Anung Madi }\end{array}$ & $\begin{array}{c}\text { Hubungan } \\
\text { Pemberian ASI } \\
\text { Eksklusif dengan } \\
\text { Kejadian Stunting } \\
\text { Pada Balita. }\end{array}$ & $\begin{array}{l}\text { Penelitian ini } \\
\text { menggunakan } \\
\text { pendekatan } \\
\text { case control } \\
\text { study }\end{array}$ & $\begin{array}{c}\text { Data diperoleh } \\
\text { dengan melakukan } \\
\text { pengukuran TB } \\
\text { terhadap anak } \\
\text { menggunakan } \\
\text { microtoise dan } \\
\text { pengisian } \\
\text { kuesioner terhadap } \\
\text { ibu. }\end{array}$ & $\begin{array}{l}\text { Berdasarkan hasil } \\
\text { penelitian ada } \\
\text { hubungan pemberian } \\
\text { ASI eksklusif dengan } \\
\text { kejadian stunting pada } \\
\text { balita. }\end{array}$ \\
\hline 14 & $\begin{array}{l}\text { Wanda } \\
\text { Lestari, Ani } \\
\text { Margawati, } \\
\text { M. Zen } \\
\text { Rahfiludin. }\end{array}$ & $\begin{array}{c}\text { Faktor risiko } \\
\text { stunting pada anak } \\
\text { umur } 6-24 \text { bulan di } \\
\text { Kecamatan } \\
\text { Penanggalan Kota } \\
\text { Subulussalam } \\
\text { Provinsi Aceh }\end{array}$ & $\begin{array}{c}\text { Desain } \\
\text { penelitian } \\
\text { adalah kasus- } \\
\text { kontrol }\end{array}$ & $\begin{array}{c}\text { Pengukuran, } \\
\text { wawancara dengan } \\
\text { kuesioner dan food } \\
\text { recall }\end{array}$ & $\begin{array}{l}\text { Hasil penelitian } \\
\text { menunjukkan bahwa } \\
\text { faktor risiko kejadian } \\
\text { stunting yaitu } \\
\text { rendahnya tingkat } \\
\text { kecukupan energi, } \\
\text { rendahnya tingkat } \\
\text { kecukupan protein, } \\
\text { tidak diberi ASI } \\
\text { eksklusif. }\end{array}$ \\
\hline 15 & $\begin{array}{l}\text { Maria Nova, } \\
\text { Olivia } \\
\text { Afriyanti. }\end{array}$ & $\begin{array}{c}\text { Hubungan Berat } \\
\text { Badan, ASI } \\
\text { eksklusif, MP-ASI } \\
\text { dan asupan energi } \\
\text { dengan stunting } \\
\text { pada Balita Usia } 24 \\
\text { - 59 Bulan di } \\
\text { Puskesmas Lubuk } \\
\text { Buaya }\end{array}$ & $\begin{array}{c}\text { Desain dalam } \\
\text { penelitian ini } \\
\text { adalah Cross } \\
\text { Sectional }\end{array}$ & $\begin{array}{c}\text { Data berat badan } \\
\text { lahir, Pemberian } \\
\text { ASI Eksklusif dan } \\
\text { Pemberian MP- } \\
\text { ASI diperoleh } \\
\text { melalui } \\
\text { wawancara } \\
\text { menggunakan } \\
\text { kuesioner. Data } \\
\text { Asupan Energi } \\
\text { diperoleh melalui }\end{array}$ & $\begin{array}{l}\text { Kesimpulannya berat } \\
\text { badan lahir, pemberian } \\
\text { MP-ASI, dan Asupan } \\
\text { Energi memiliki } \\
\text { hubungan yang } \\
\text { signifikan dengan } \\
\text { kejadian stunting pada } \\
\text { balita usia } 24-59 \\
\text { bulan dan pemberian } \\
\text { ASI Eksklusif tidak } \\
\text { memiliki hubungan }\end{array}$ \\
\hline
\end{tabular}




\begin{tabular}{|c|c|c|c|c|c|}
\hline No & Penulis & Judul Penelitian & $\begin{array}{c}\text { Metode } \\
\text { Penelitian }\end{array}$ & Instrumen & Hasil \\
\hline & & & & $\begin{array}{l}\text { wawancara dengan } \\
\text { menggunakan } \\
\text { Food Frequency } \\
\text { Questionaire } \\
\text { (FFQ). }\end{array}$ & $\begin{array}{l}\text { yang tidak signifikan } \\
\text { dengan kejadian } \\
\text { stunting pada balita } \\
\text { usia } 24-59 \text { bulan. }\end{array}$ \\
\hline 16 & Lidia Fitri & $\begin{array}{c}\text { Hubungan BBLR } \\
\text { dan ASI Ekslusif } \\
\text { dengan Kejadian } \\
\text { Stunting di } \\
\text { Puskesmas Lima } \\
\text { Puluh Pekanbaru }\end{array}$ & $\begin{array}{c}\text { Jenis } \\
\text { penelitian ini } \\
\text { adalah } \\
\text { analitik } \\
\text { kuantitatif } \\
\text { dengan } \\
\text { desain cross- } \\
\text { sectional }\end{array}$ & kuesioner & $\begin{array}{l}\text { Dapat disimpulkan } \\
\text { terdapat hubungan } \\
\text { antara BBLR dan ASI } \\
\text { eksklusif dengan } \\
\text { kejadian stunting. }\end{array}$ \\
\hline 17 & $\begin{array}{l}\text { Sofia } \\
\text { Mawaddah }\end{array}$ & $\begin{array}{c}\text { Hubungan } \\
\text { Pemberian ASI } \\
\text { Eksklusif dengan } \\
\text { Kejadian Stunting } \\
\text { pada Balita Usia } 24 \\
-36 \text { Bulan }\end{array}$ & $\begin{array}{c}\text { Metode } \\
\text { penelitian } \\
\text { analitik } \\
\text { observasional } \\
\text { dengan } \\
\text { pendekatan } \\
\text { kontrol } \\
\text { retrospektif. }\end{array}$ & $\begin{array}{c}\text { Data diperoleh } \\
\text { dari buku register } \\
\text { Puskesmas } \\
\text { Tampang } \\
\text { Tumbang Anjir } \\
\text { dan data primer } \\
\text { diperoleh dari } \\
\text { isian format isian } \\
\text { yang ditanyakan } \\
\text { pada ibu yang } \\
\text { memiliki balita } \\
\text { usia } 24 \text { - } 36 \text { bulan. }\end{array}$ & $\begin{array}{l}\text { Ada hubungan yang } \\
\text { bermakna antara } \\
\text { pemberian ASI } \\
\text { eksklusif dan kejadian } \\
\text { stunting pada usia } 24- \\
36 \text { bulan }\end{array}$ \\
\hline 18 & $\begin{array}{l}\text { Lidia Fitri, } \\
\text { Ernita }\end{array}$ & $\begin{array}{c}\text { Hubungan } \\
\text { Pemberian ASI } \\
\text { Eksklusif dan MP- } \\
\text { ASI Dini dengan } \\
\text { Kejadian Stunting } \\
\text { Pada Balita }\end{array}$ & $\begin{array}{c}\text { Merupakan } \\
\text { penelitian } \\
\text { analitik } \\
\text { kuantitatif } \\
\text { dengan } \\
\text { desain case } \\
\text { control } \\
\text { dengan } \\
\text { pendekatan } \\
\text { retrospektif } \\
\end{array}$ & Kuesioner & $\begin{array}{l}\text { Terdapat hubungan } \\
\text { yang signifikan antara } \\
\text { ASI eksklusif dan } \\
\text { pemberian MP ASI } \\
\text { dini dengan kejadian } \\
\text { stunting }\end{array}$ \\
\hline 19 & $\begin{array}{l}\text { Dini } \\
\text { Nugraheni, } \\
\text { Nuryanto, } \\
\text { Hartanti } \\
\text { Sandi } \\
\text { Wijayanti, } \\
\text { Binar } \\
\text { Panunggal, } \\
\text { Ahmad } \\
\text { Syauqy }\end{array}$ & $\begin{array}{c}\text { ASI Eksklusif dan } \\
\text { Asupan Energi } \\
\text { Berhubungan } \\
\text { dengan Kejadian } \\
\text { Stunting pada Usia } 6 \\
\text { - } 24 \text { Bulan di Jawa } \\
\text { Tengah }\end{array}$ & $\begin{array}{c}\text { Penelitian ini } \\
\text { menggunakan } \\
\text { rancangan } \\
\text { studi analitik } \\
\text { observasional } \\
\text { dengan } \\
\text { pendekatan } \\
\text { Cross- } \\
\text { sectional }\end{array}$ & $\begin{array}{c}\text { Data Variabel } \\
\text { bebas pada } \\
\text { penelitian ini } \\
\text { didapatkan dengan } \\
\text { pengisian } \\
\text { kuesioner dan } \\
\text { hasil wawancara } \\
\text { oleh tim } \\
\text { Manajemen data } \\
\text { dari Direktorat } \\
\text { Gizi Masyarakat } \\
\text { dan Balitbangkes } \\
\text { Kementerian } \\
\text { Kesehatan. }\end{array}$ & $\begin{array}{l}\text { Determinan faktor } \\
\text { yang paling } \\
\text { berhubungan dengan } \\
\text { kejadian stunting } \\
\text { dilihat berdasarkan } \\
\text { variabel pada } \\
\text { penelitian ini yaitu } \\
\text { riwayat inisiasi } \\
\text { menyusu dini (IMD), } \\
\text { riwayat ASI Eksklusif, } \\
\text { asupan energi, dan } \\
\text { asupan protein }\end{array}$ \\
\hline
\end{tabular}




\begin{tabular}{|c|c|c|c|c|c|}
\hline No & Penulis & Judul Penelitian & $\begin{array}{c}\text { Metode } \\
\text { Penelitian }\end{array}$ & Instrumen & Hasil \\
\hline 20 & $\begin{array}{l}\text { Eko } \\
\text { Setiawan, } \\
\text { Rizanda } \\
\text { Machmud, } \\
\text { Masrul }\end{array}$ & $\begin{array}{l}\text { Faktor-faktor yang } \\
\text { berhubungan dengan } \\
\text { Kejadian Stunting } \\
\text { pada Anak Usia } 24- \\
59 \text { Bulan di Wilayah } \\
\text { Kerja Puskesmas } \\
\text { Andalas Kecamatan } \\
\text { Padang Timur Kota } \\
\text { Padang Tahun } 2018\end{array}$ & $\begin{array}{l}\text { Penelitian ini } \\
\text { merupakan } \\
\text { studi analitik } \\
\text { observasional } \\
\text { dengan } \\
\text { desain cross- } \\
\text { sectional }\end{array}$ & $\begin{array}{l}\text { Microtoise dan } \\
\text { kuesioner. }\end{array}$ & $\begin{array}{l}\text { Terdapat hubungan } \\
\text { yang bermakna antara } \\
\text { tingkat asupan energi } \\
\text { dengan kejadian } \\
\text { stunting. Tingkat } \\
\text { asupan protein tidak } \\
\text { menunjukkan } \\
\text { hubungan yang } \\
\text { signifikan dengan } \\
\text { kejadian stunting. }\end{array}$ \\
\hline 21 & $\begin{array}{l}\text { Delmi } \\
\text { Sulastri }\end{array}$ & $\begin{array}{c}\text { Faktor Determinan } \\
\text { Kejadian Stunting } \\
\text { pada Anak Usia } \\
\text { Sekolah di } \\
\text { Kecamatan Lubuk } \\
\text { Kilangan Kota } \\
\text { Padang }\end{array}$ & $\begin{array}{l}\text { Penelitian } \\
\text { dengan } \\
\text { desain cross } \\
\text { sectional } \\
\text { study }\end{array}$ & $\begin{array}{l}\text { pengukuran tinggi } \\
\text { badan (TB) } \\
\text { menggunakan } \\
\text { microtoice dengan } \\
\text { ketelitian } 0,1 \mathrm{~cm} \\
\text { dan pada ibunya } \\
\text { dilakukan } \\
\text { wawancara, } \\
\text { sedangkan untuk } \\
\text { menghitung } \\
\text { asupan energi dan } \\
\text { protein dilakukan } \\
\text { melalui } \\
\text { wawancara } \\
\text { menggunakan } \\
\text { semi kuantitatif } \\
\text { Food Frequency } \\
\text { Questionaire } \\
\text { (FFQ), Status gizi } \\
\text { stunting } \\
\text { ditegakkan } \\
\text { berdasarkan } \\
\text { kriteria tinggi } \\
\text { badan apabila } \\
\text { berada <-2 SD. }\end{array}$ & $\begin{array}{l}\text { Hasil penelitian ini } \\
\text { menunjukkan hubungan } \\
\text { yang tidak bermakna } \\
\text { antara asupan protein } \\
\text { dengan status gizi ( } \mathrm{p}> \\
0,05 \text { ), dimana anak } \\
\text { pendek lebih banyak } \\
\text { terdapat pada asupan } \\
\text { protein kurang. }\end{array}$ \\
\hline
\end{tabular}

\section{PEMBAHASAN}

\section{Pengaruh Asupan Energi Protein terhadap Stunting}

Proses pertumbuhan sangat ditentukan oleh kecukupan total makanan/asupan energi yang dikonsumsi. Semakin optimal jumlah asupan energi yang dikonsumsi akan semakin ideal pula proses pertumbuhan manusia. Dan sebaliknya jika asupan makanan/energi yang dikonsumsi kurang dari kebutuhan tubuh maka akan mengakibatkan terhambatnya proses pertumbuhan sehingga mengakibatkan stunting, bahkan dapat mengarah ke kondisi malnutrisi (Sugiyanto, S., \& Sumarlan, S. 2021).

Pemenuhan kebutuhan gizi seimbang untuk pertumbuhan bukan hanya tentang asupan energi saja, tetapi juga terkait dengan asupan protein. Asupan protein balita dibagi menjadi dua kategori, yaitu rendah dan cukup. Kategori asupan protein rendah apabila $<100 \%$ AKG dan kategori asupan cukup apabila $\geq 100 \%$ dari AKG (Sugiyanto, S., \& Sumarlan, S. 2021).

Protein terdiri dari asam-asam amino. Di samping menyediakan asam amino esensial, protein juga menyuplai energi dalam keadaan terbatas dari karbohidrat dan lemak. Protein merupakan salah satu zat gizi makro yang berfungsi sebagai zat pembangun, pemelihara sel dan jaringan tubuh serta membantu dalam metabolisme sistem kekebalan tubuh seseorang. Protein yang berasal dari makanan akan dicerna dan diubah menjadi asam amino yang berfungsi sebagai prekursor dari neurotransmitter dan berperan dalam perkembangan otak anak 
(Lobo, W. I., Talahatu, A. H., \& Riwu, R. R. 2019).

Terdapat tujuh artikel yang membahas tentang pengaruh asupan energi protein terhadap stunting. Dari ketujuh artikel tersebut ada dua artikel yang menjelaskan bahwa tidak terdapat hubungan yang signifikan antara asupan energi protein dengan kejadian stunting. Hal ini dapat terjadi karena asupan protein yang dikonsumsi dijadikan sebagai sumber energi. Dimana protein merupakan salah satu sumber energi utama bagi tubuh. Dan akan terjadi pemecahan protein apabila asupan energi tidak adekuat.

Berdasarkan karakteristik jenis kelamin responden dari ketujuh artikel tersebut menunjukkan bahwa didominasi oleh jenis kelamin perempuan dan rata-rata usia responden yaitu berusia 12 bulan sampai dengan usia 59 bulan.

Pada penelitian yang dilakukan oleh Utami A. D dkk (2017) menjelaskan bahwa kejadian stunting dipengaruhi oleh asupan energi protein. Pada penelitian Sugiyanto dan Samarlan (2020) menjelaskan bahwa kejadian stunting memiliki hubungan yang signifikan dengan asupan protein. Penelitian yang dilakukan oleh Welmince I. L dkk (2019) juga menjelaskan bahwa stunting dipengaruhi oleh tingkat kecukupan protein. Hasil penelitian yang dilakukan oleh Intje $\mathrm{P}$ dan Sarci $\mathrm{M}$. T (2012) juga menunjukkan bahwa asupan protein berhubungan dengan stunting. Pada penelitian yang dilakukan Wanda L dkk (2012) Menunjukkan bahwa faktor risiko Stunting adalah asupan protein tidak adekuat.

Sesuai dengan teori bahwa protein berfungsi sebagai zat pembangun. Dimana seluruh lapisan sel terdiri atas protein yang membawa mikronutrien. Protein juga berfungsi sebagai pengatur tubuh dan membentuk DNA baru bagi tubuh. Sehingga jika tubuh kekurangan protein dalam jangka waktu yang panjang maka akan terganggunya regulasi tubuh dan hormon pertumbuhan dapat terganggu dan menyebabkan gangguan gizi seperti stunting (Fitri, L., Ritawani, E., \& Mentiana, Y,2020).

Hasil penelitian yang dilakukan oleh Eko S di wilayah kerja Puskesmas Andalas Kota Padang dari bulan Agustus sampai bulan April 2018 memperoleh hasil dimana asupan energi protein tidak menunjukkan hubungan yang signifikan dengan kejadian stunting. Hasil penelitian yang dilakukan oleh Sulastri (2012) juga menunjukkan hasil yang sama dimana hasil uji statistik menunjukkan bahwa tidak terdapat hubungan antara asupan energi protein dengan stunting.

Kejadian ini dapat disebabkan karena asupan protein yang dikonsumsi dijadikan sebagai sumber energi. Dimana protein merupakan satu dari tiga sumber energi utama bagi tubuh manusia. Pemecahan protein akan terjadi jika asupan energi tidak adekuat. Apabila diet tidak mengandung protein dan/atau energi dalam jumlah yang cukup maka tubuh akan mengalami defisiensi protein (Setiawan, E., Machmud, R., \& Masrul, M,2018).

Terdapatnya hubungan yang tidak bermakna antara asupan energi dengan status gizi, kemungkinan disebabkan adanya faktorfaktor lain yang mempengaruhi status gizi seseorang. Faktor tersebut diantaranya adalah aktivitas fisik, riwayat penyakit, kebiasaan jajan, yang pada penelitian ini tidak di teliti (Sulastri, D,2012).

\section{Pengaruh Riwayat ASI Eksklusif terhadap Stunting}

ASI sangat dibutuhkan dalam masa pertumbuhan bayi agar kebutuhan gizinya tercukupi. Oleh karena itu ibu harus dan wajib memberikan ASI secara eksklusif kepada bayi sampai umur bayi 6 bulan dan tetap memberikan ASI sampai bayi berumur 2 tahun untuk memenuhi kebutuhan gizi bayi (Alrahmad, Miko, \& Hadi, 2010).

Panjang anak juga berhubungan dengan Pemberian ASI. Durasi menyusui positif berhubungan dengan pertumbuhan panjang, semakin lama anak-anak disusui maka semakin cepat pula mereka tumbuh baik pada tahun kedua dan pada tahun ketiga kehidupan (Nova, 2018). Anak yang tidak diberikan ASI eksklusif pada usia $0-6$ bulan dan pemberian MP-ASI yang tidak sesuai, anak akan dapat berdampak stunting dan akan sering terkena infeksi (Nugraheni, D., Nuryanto, N., Wijayanti, H. S., Panunggal, B., \& Syauqy, A,2020).

Terdapat delapan belas artikel yang membahas tentang pengaruh ASI eksklusif terhadap stunting. Sebagian besar artikel tersebut menjelaskan bahwa riwayat pemberian ASI eksklusif berpengaruh terhadap stunting. Tetapi terdapat tiga artikel penelitian menjelaskan bahwa ASI eksklusif tidak berpengaruh secara signifikan terhadap 
stunting. Ini membuktikan bahwa stunting pada bayi tetapi dapat juga dipengaruhi oleh asupan makanan selain ASI termasuk salah satunya adalah asupan energi dan protein pada makanan pendamping ASI.

Pada penelitian yang dilakukan oleh Sugiyanto dan Sumarlan di wilayah kerja Puskesmas Limbong Kabupaten Luwu Utara Provinsi Sulawesi Selatan, menunjukkan bahwa ASI eksklusif memiliki hubungan yang signifikan dengan terjadinya stunting. Penelitian yang dilakukan oleh Izah dkk tahun 2020 menunjukkan pemberian ASI eksklusif berpengaruh terhadap kejadian stunting pada balita. Pada penelitian yang dilakukan oleh Khoirun Ni'mah dan Siti Rahayu Nadhiroh (2015), menunjukkan bahwa balita yang tidak mendapatkan ASI Eksklusif selama 6 bulan pertama lebih tinggi pada kelompok balita stunting $(88,2 \%)$ dibandingkan dengan kelompok balita normal $(61,8 \%)$. Pada penelitian yang dilakukan oleh Sinambela dkk (2019) menjelaskan bahwa terdapat pengaruh yang signifikan antara pemberian ASI eksklusif dengan kejadian stunting pada balita di wilayah kerja puskesmas Teluk Tiram Banjarmasin. Berdasarkan hasil penelitian yang dilakukan oleh Erika Fitria Lestari dan Luluk Khusnul Dwihestie (2020) menunjukkan bahwa adanya hubungan pemberian ASI Eksklusif dengan kejadian stunting. Penelitian yang dilakukan oleh Dewi (2015) menunjukkan bahwa status stunting mempunyai kaitan dengan pemberian ASI Eksklusif pada balita di Kabupaten Gunung Kidul. Pada penelitian yang dilakukan oleh Sampe dkk (2020), menunjukkan ada hubungan pemberian ASI eksklusif dengan kejadian stunting pada balita. Sedangkan pada uji odds ratio didapatkan balita yang tidak diberikan ASI eksklusif berpeluang 61 kali lipat mengalami stunting dibandingkan balita yang diberi ASI eksklusif. Penelitian yang dilakukan oleh Wanda Lestari dkk (2014) menunjukkan bahwa ada hubungan antara ASI eksklusif dengan stunting.. Penelitian yang dilakukan oleh Fitri (2017) menunjukkan bahwa terdapat hubungan antara pemberian ASI ekslusif dengan kejadian. Penelitian yang dilakukan oleh Sofia Mawaddah (2019), Hasil uji statistik menunjukkan ada hubungan yang bermakna antara pemberian ASI eksklusif dan kejadian stunting pada usia 24-36 bulan. Penelitian yang dilakukan oleh Lidia Fitri dan Ernita (2018) dimana hasil uji menunjukkan bahwa ada hubungan pemberian ASI eksklusif dengan stunting. Pada penelitian yang dilakukan oleh Dini Nugraheni dkk (2020) menjelaskan bahwa stunting berhubungan dengan riwayat ASI Eksklusif.

Dari hasil-hasil penelitian tersebut dapat dijelaskan bahwa pemberian ASI eksklusif bagi bayi sampai usia 6 bulan sangat berpengaruh untuk menurunkan risiko stunting pada anak. Namun pentingnya pemberian ASI eksklusif belum sepenuhnya disadari oleh masyarakat. Persentase Bayi kurang dari 6 bulan mendapat ASI Eksklusif secara nasional sekitar 66,1\% (Kemenkes RI,2020).

ASI merupakan bentuk makanan ideal untuk memenuhi gizi anak, karena ASI sanggup memenuhi kebutuhan gizi bayi untuk hidup selama 6 bulan pertama kehidupan. ASI merupakan sumber makanan yang penting bagi kesehatan bayi. ASI dapat memenuhi tiga perempat dari kebutuhan protein bayi usia $6-$ 12 bulan, selain itu ASI juga mengandung semua asam amino esensial yang dibutuhkan bayi (Izah, N., Zulfiana, Ev., \& Rahmanindar, N,2020).

Adanya perbedaan hasil pada penelitian ini banyak faktor yang dapat menyebabkan terjadinya stunting dan ASI eksklusif bukan satu-satunya penyebab stunting. Tetapi juga ada penyebab lain seperti asupan makanan selain ASI karena kebutuhan zat gizi yang tinggi, khususnya setelah masa pemberian ASI eksklusif dan pada penderita penyakit infeksi (Cynthia, C., Bikin Suryawan, I. W., \& Widiasa, A. M, 2019). Keadaan stunting tidak hanya ditentukan oleh faktor status pemberian ASI eksklusif, tetapi juga dipengaruhi oleh faktor lain seperti: kualitas Makanan Pendamping ASI (MP-ASI), kecukupan asupan gizi yang diberikan kepada anak setiap hari, serta status kesehatan bayi (Setiawan, E., Machmud, R., \& Masrul, M, 2018).

\section{KESIMPULAN DAN SARAN}

Adapun kesimpulan yang diperoleh dari penelitian ini yaitu: Ada pengaruh asupan energi protein dan riwayat ASI eksklusif dengan kejadian stunting. Hasil penelitian ini diharapkan menjadi salah satu bahan edukasi dan intervensi keperawatan yang dapat diterapkan di pelayanan kesehatan dalam mencegah stunting.

Saran yang dapat diberikan antara lain diharapkan kepada Dinas kesehatan melakukan 
upaya peningkatan pengetahuan tentang penyebab dan dampak dari stunting, serta pihak puskesmas perlu melakukan penyuluhan yang berkesinambungan tentang ASI eksklusif dan upaya memenuhi kebutuhan energi dan protein pada balita.

\section{DAFTAR PUSTAKA}

Alrahmad, A. H., Miko, A., \& Hadi, A. (2010). Kajian Stunting pada anak balita ditinjau dari pemberian ASI ekslusif, MP-ASI, status imunisasi dan karakteristik keluarga di kota Banda Aceh. Jurusan Gizi Poltekkes Kemenkes RI Aceh, 1-13

Aridiyah, F. O., Rohmawati, N., \& Ririanty, M. (2015). Faktor-faktor yang Mempengaruhi Kejadian Stunting pada Anak Balita di Wilayah Pedesaan dan Perkotaan (The Factors Affecting Stunting on Toddlers in Rural and Urban Areas). 3(1).

Badan Penelitian dan Pengembangan Kesehatan. (2018). Laporan Riskesdas Sulawesi Barat. 249.

Badan Penelitian dan Pengembangan Kesehatan. (2018). Laporan_Nasional_RKD2018_FINAL.pd f. In Badan Penelitian dan Pengembangan Kesehatan (p. 198). http://labdata.litbang.kemkes.go.id/image s/download/laporan/RKD/2018/Laporan_ Nasional_RKD2018_FINAL.pdf

Basri, N., Sididi, M., \& Sartika. (2021). Faktor yang Berhubungan dengan Kejadian Stunting pada Balita (24-36 Bulan). Window of Public Health Journal, 416425. https://doi.org/10.33096/ woph. v1i5.98

Cynthia, C., Bikin Suryawan, I. W., \& Widiasa, A. . M. (2019). Hubungan ASI eksklusif dengan Kejadian Stunting pada Anak Usia 12-59 bulan di RSUD Wangaya Kota Denpasar. Jurnal Kedokteran Meditek, 25(1), 29-35. https://doi.org/ 10.36452/jkdoktmeditek.v25i1. 1733.

Dewi, D. P. (2015). Status Stunting Kaitannya Dengan Pemberian Asi. Jurnal Medika Respatiespati, 10, 60-66.

Dwi Utami, A., Lanti, Y., \& Dewi, R. (2017). The Effect of Nutrient Intake and Socioeconomic Factor toward Stunting Incidence among Primary School Students in Surakarta. Journal of Epidemiologi and Publich Health, 2(1),
1-10. https://doi.org/jepublichealth. 2017.02.01.01.

Fitriami, E., \& Huriah, T. (2019). Determinan kejadian Stunting pada Anak di Indonesia : A Literature Review. Jurnal Smart Keperawatan, 6(2), 113. https://doi.org/10.34310/jskp.v6i2.190

Fitri, L. (2018). Hubungan BBLR dan ASI Ekslusif dengan Kejadian Stunting di Puskesmas Lima Puluh Pekanbaru. Jurnal Endurance, 3(1), 131. https://doi.org/10.22216/jen.v3i1.1767.

Fitri, L., \& Ernita. (2019). Hubungan Pemberian ASI Eksklusif dan MP ASI Dini dengan Kejadian Stunting Pada Balita. Jurnal Ilmu Kebidanan, 8(1), 1924.

Fitri, L., Ritawani, E., \& Mentiana, Y. (2020). Jurnal Endurance: Kajian Ilmiah Problema Kesehatan Hubungan Asupan Energi dengan Kejadian Stunting Pada Balita Usia 2-5 Tahun Kota Pekanbaru. Jurnal Endurance Kajian Ilmiah Problema Kesehatan, 5(3), 591-597.

Handayani, S., Kapota, W. N., \& Oktavianto, E. (2019). Hubungan Status Asi Eksklusif Dengan Kejadian Stunting Pada Batita Usia 24-36 Bulan Di Desa Watugajah Kabupaten Gunungkidul. Medika Respati : Jurnal Ilmiah Kesehatan, 14(4), 287.

Indriyan, E., DewI, Y. L. R., \& Salimo, H. (2018). Biopsychosocial Determinants of Stunting in Children Under Five: A Path Analysis Evidence from the Border Area West Kalimantan. Journal of Maternal and Child Health, 03(02), 146-155. https://doi.org/10.26911/thejmch.2018.03 .02 .07

Izah, N., Zulfiana, Ev., \& Rahmanindar, N. (2020). Analisis Sebaran Dan Determinan Stunting Pada Balita Berdasarkan Pola Asuh (Status Imunisasi Dan Pemberian Asi Eksklusif). Jurnal Ilmu Keperawatan Dan Kebidanan, 11(1), 27. https://doi.org/10.26751/ jikk.v11i1.764

Kemenkes RI. (2018). Buletin Stunting. Kementerian Kesehatan RI, 301(5), 1163-1178.

Kemenkes RI. (2020). Profil Kesehatan Indonesia Tahun 2019. Kementerian Kesehatan RI, https://doi.org/10.5005/jp/books/11257_5

Lestari, E.F., \& Dwihestie, L. K. (2020). ASI 
Eksklusif Berhubungan dengan Kejadian Stunting pada Balita. Jurnal Ilmiah Permas: Jurnal Ilmiah STIKES Kendal, 10(2), 129-136.

Lestari,W., Margawati, A., \& Rahfiludin, Z. (2014). Risk factors for stunting in children aged 6-24 months in the subdistrict of Penanggalan, Subulussalam, Aceh Province. Jurnal Gizi Indonesia (The Indonesian Journal of Nutrition), 3(1), 37-45. https://ejournal.undip.ac.id/ index.php/jgi/article/ view/8752/7081.

Lobo, W. I., Talahatu, A. H., \& Riwu, R. R. (2019). Faktor Penentu Kejadian Stunting pada Anak Balita di Wilayah Kerja Puskesmas Alak Kota Kupang. Media Kesehatan Masyarakat, 1(2), 5967. https://doi.org/10.35508/ mkm.v1i2. 1953.

Nova, M., \& Afriyanti, O. (2018). Hubungan Berat Badan, Asi Eksklusif, Mp-Asi Dan Asupan Energi Dengan Stunting Pada Balita Usia 24-59 Bulan di Puskesmas Lubuk Buaya. JURNAL KESEHATAN PERINTIS (Perintis's Health Journal), 5(1), 39-45. https://doi.org/10.33653/jkp. v5i1.92

Nugraheni, D., Nuryanto, N., Wijayanti, H. S., Panunggal, B., \& Syauqy, A. (2020). Asi Eksklusif Dan Asupan Energi Berhubungan Dengan Kejadian Stunting Pada Usia 6 - 24 Bulan Di Jawa Tengah. Journal of Nutrition College, 9(2), 106113.

https://doi.org/10.14710/jnc.v9i2.27126

Picauly, I., \& Toy, S. M. (2013). Analisis Determinan dan Pengaruh Stunting Terhadap Prestasi Belajar Anak Sekolah Di Kupang Dan Sumba Timur, NTT. Jurnal Gizi Dan Pangan, 8(1), 55. https://doi.org/10.25182/jgp.2013.8.1.5562

Setiawan, E., Machmud, R., \& Masrul, M. (2018). Faktor-Faktor yang Berhubungan dengan Kejadian Stunting pada Anak Usia 24-59 Bulan di Wilayah Kerja Puskesmas Andalas Kecamatan Padang Timur Kota Padang Tahun 2018. Jurnal Kesehatan Andalas, 7(2), 275.

Sinambela, D. P., Darsono, P. V., \& Hidayah, N. (2020). Pengaruh Riwayat Pemberian ASI Eksklusif Dengan Kejadian Stunting Pada Balita di Wilayah Kerja Puskesmas Teluk Tiram Banjarmasin. Dinamika Kesehatan Jurnal Kebidanan Dan Keperawatan, 10(1), 102-111.

SJMJ, S. A. S., Toban, R. C., \& Madi, M. A. (2020). Hubungan Pemberian ASI Eksklusif Dengan Kejadian Stunting Pada Balita. Jurnal Ilmiah Kesehatan Sandi Husada, 11(1), 448-455. https://doi.org/10.35816/jiskh.v11i1.314

Sugiyanto, S., \& Sumarlan, S. (2021). Analisa Faktor Yang Berhubungan Dengan Stunting Pada Balita Usia 25-60 Bulan. JURNAL KESEHATAN PERINTIS (Perintis's Health Journal), 7(2), 9-20. https://doi.org/10.33653/jkp.v7i2.485

Sulastri, D. (2012). Faktor Determinan Kejadian Stunting Pada Anak Usia Sekolah Di Kecamatan Lubuk Kilangan Kota Padang. Majalah Kedokteran Andalas, 36(1), 39. https://doi.org/10. 22338/ mka.v36.i1.p39-50.2012

Wijayanti, F., Pramulya S, I., \& Saparwati, M. (2020). Hubungan Pemberian ASI Eksklusif Dengan Kejadian Stunting Pada Balita Usia 24-60 Bulan. Jurnal Kesehatan Kusuma Husada, 35-41. https://doi.org/10.34035/jk.v12i1.545. 